Journal of Conflict \& Security Law (C) Oxford University Press 2015; all rights reserved. For permissions, please e-mail: journals.permissions@oup.com doi: $10.1093 /$ jcsl/krv022

Advance Access published on 24 November 2015

\title{
Bridging the Security Gap through EU Rule of Law Missions? Rule of Law Administration by EULEX
}

\author{
Tilmann Altwicker* and Nuscha Wieczorek ${ }^{\dagger}$
}

\begin{abstract}
EU civilian missions are a tool to bridge new security gaps. They focus on security problems that cannot be adequately addressed by military capabilities alone. These missions operationalize the idea of liberal peace, ie the link between the (democratic, liberal etc.) 'quality' of domestic institutions and international peace. The purpose of these missions is to reform (or establish) a State security sector based upon these qualities.

Taking the most advanced EU civilian mission to date, EULEX Kosovo, as an object of study, this article examines a particular legal problem that ensues when the rule of law is 'exported': in order to fulfil its rule of law-exporting task, the mission enjoys broad executive powers. This, in turn, requires that the mission itself must be bound by the principles it seeks to 'export'. The rule of law serves, in other words, both as a policy-tool and as a constraint for EULEX. As both dimensions are connected, the failure of one will likely affect the performance of the other.

The article concludes that while the hybrid approach to the rule of law by EULEX is a promising tool to address security gaps resulting from new threats in post-conflict societies, the present weakness of the constraint function negatively affects the performance of the mission as a whole.
\end{abstract}

\section{Introduction}

The idea that 'public security' can be exported by international actors is nothing new. ${ }^{1}$ Beginning in the 1960 s, public security-export has been an important feature of the UN administration of territories. ${ }^{2}$ By means of UN missions,

* Dr. iur., LLM (CEU), Head of the Research Group on 'Transnational Public Security Law', University of Basel; Email: tilmann.altwicker@unibas.ch.

$\dagger$ MLaw, LLM (Columbia), Research Fellow, University of Basel; Email: nuscha.wieczorek@unibas.ch.

1 'Public security' pertains to the management of risks attributable to the conduct of non-state agents in relation to protected individual legal interests (eg life, health, liberty, property) but also in relation to protected collective legal interests (eg the functioning of public and civil society institutions).

2 An early UN mission in the Congo (ONUC), the UN Operation in Somalia (UNOSOM II) and the UN Transitional Administration in East Timor (UNTAET) built on this idea. See UNSC Res 143 (14 July 1960) UN Doc S/RES/4387, para 2; UNSC Res 814 (26 March 1993) UN Doc S/RES/814, paras 12, 14; UNSC Res 1272 (25 October 1999) UN Doc S/RES/1272, paras 2(a), 3(a). On the international administration of territories see generally, M Benzing, 'International Administration of 
the international community exercised (to a varying degree) public security powers that are normally assigned to the territorial State, eg the protection of civilians (from physical violence), the disarmament of non-State actors, the protection of critical infrastructures, the maintenance of corrections facilities, border management, etc.

Public security-export is not a UN monopoly. The EU followed the UN's lead in the beginning of the 2000s. Since then, the EU has acted as a security-exporter by operating several civilian missions as a response to the emergence of newly perceived security threats. ${ }^{3}$ In its 2003 Security Strategy, the EU diagnosed that post-Cold War security threats are no longer of a purely military nature and therefore cannot be adequately addressed by an exclusively military response. ${ }^{4}$ Dynamic threats, such as terrorism, organized crime, failed States or regional conflicts resulting in new 'security gaps', call for a multi-instrumental approach, not only deploying military, but also civilian capabilities. ${ }^{5}$ Civilian crisis management by EU missions has been one response to address new 'security gaps' and figures as a central tool of European external politics today. ${ }^{6}$ With their unique focus on the provision of public security by means of strengthening $c i$ vilian capabilities, such as police or rule of law institutions, EU civilian missions attempt to address 'security gaps' that cannot be remedied by the sole employment of military capabilities. ${ }^{7}$

Territories' (MPEPIL 2010) <http:/opil.ouplaw.com/view/10.1093/law:epil/ 9780199231690/law-9780199231690-e1297? rskey=oaXvu9\&result=1\&prd=EPIL $>$ accessed 18 May 2015; C Stahn, 'UN Transitional Administrations in Kosovo and East Timor: A First Analysis' (2001) 5 Max Planck UNYB 103; R Wilde, 'From Danzig to East Timor and Beyond: The Role of International Territorial Administration' (2001) 95 AJIL 583; R Wolfrum, 'International Administration in Post-Conflict Situations by the United Nations and Other International Actors' (2005) 9 Max Planck UNYB 649; B Knoll, The Legal Status of Territories Subject to Administration by International Organizations (CUP 2008); C Stahn, The Law and Practice of International Territorial Administration: Versailles to Iraq and Beyond (CUP 2008); R Wilde, International Territorial Administration: How Trusteeship and the Civilizing Mission Never Went Away (OUP 2008).

3 For an overview of the ongoing EU civilian missions see $<\mathrm{http}: / /$ www.eeas.europa.eu/ csdp/missions-and-operations/index_en.htm > accessed 18 May 2015. For a detailed analysis of EU civilian missions see P Koutrakos, The EU Common Security and Defence Policy (OUP 2013) 133-82.

4 European Security Strategy, 'A Secure Europe in a Better World' (2003) $7<$ http:// www.consilium.europa.eu/uedocs/cmsUpload/78367.pdf> accessed 18 May 2015.

5 ibid 11. See also S Keukeleire and T Delreux, The Foreign Policy of the European Union (Palgrave and Macmillan 2014) 181-5 (on the civilian dimension of the Common Security and Defence Policy of the EU).

6 M Kaldor, 'The EU as a New Form of Political Authority: The Example of the Common Security and Defence Policy' (2012) 3 Global Policy Volume 79, 82. Some EU civilian missions place a focus on border security and customs operations (eg EUBAM Rafah), others on police and justice sector reform (eg EUPOL Afghanistan).

7 Human Security Study Group, 'A European Way of Security: The Madrid Report of the Human Security Study Group Comprising a Proposal and Background Report' 
Some EU civilian missions are explicitly framed as 'rule of law'-exporting missions. ${ }^{8}$ While there is an intuitive connection between the 'rule of law' (RoL) and 'public security', the particular design of EU 'rule of law'-exporting missions is more complex. The foundational idea of such missions is the following: the RoL and the provision of law-based procedures for social cooperation and conflict resolution cater to public security. The existence of public security, in turn, is considered a condition of interstate peace, as a large number of grave conflicts today are rooted in domestic tensions and violence. The idea that the RoL and international peace are connected can be traced back primarily to Immanuel Kant, who proclaimed that republican states will form a pacific union and refrain from engaging in war with each other as a result of their particular civil constitution. ${ }^{9}$ In more recent times, the Kantian approach has been recast as the idea of 'liberal peace', ie the belief that 'perfect' (State and societal) institutions (democratic government, liberal economy, RoL-based legal system) lead to international peace and security. ${ }^{10}$ Jack Levy, for example, is famously known for stating that "the absence of war between democracies comes as close as anything we have to an empirical law in international relations". ${ }^{11}$ The idea of liberal peace also constitutes a philosophical foundation for EU civilian missions: RoL-abiding institutions can be established with the support of the European mission that cater to public security domestically and to international peace.

The main argument made by the article is this: if the idea of EU civilian missions is to 'export' the RoL, the mission must-depending on its mandate-adopt a complex, hybrid approach to the RoL. The hybridity results from a 'double' application of the idea of liberal peace. First, the RoL serves as a policy-tool to establish and maintain public security and, consequently, international peace. The idea is to rebuild or establish RoL-conforming (security) structures and institutions (such as police, public prosecutor's office and courts). This is in line with the idea of liberal peace as applied to a post-conflict society. Second, the RoL serves as

(Madrid, 8 November 2007) $12<$ http://eprints.lse.ac.uk/40207/1/A_European_Way_ of_Security(author).pdf > accessed 18 May 2015.

8 EUJUST LEX-Iraq, the European Union Integrated Rule of Law Mission for Iraq (completed by 31 December 2013) or EUJUST THEMIS, the Rule of Law Mission to Georgia (completed by 14 July 2005).

9 I Kant, 'Perpetual Peace. A Philosophical Sketch' in H Reiss (ed), Kant: Political Writings (2nd edn, CUP 1997) 93, 99-100. M Doyle, 'Liberalism and World Politics' (1986) 80 American Political Science Rev 1151, 1157f. (expounding Kant's discussion of the implications of juridical freedom).

10 On the concept of liberal peace see BJ Ryan, Statebuilding and Police Reform: The Framework of Security (Routledge 2011) 3; J Mac Millan, On Liberal Peace: Democracy, War and the International Order (Tauris Academic Studies 1998). There is a growing quantitative literature on the link between the quality of domestic institutions and international security, for an overview see, ED Mansfield and JC Pevehouse, 'Quantitative Approaches' in C Reuss-Smit and D Snidal (eds), The Oxford Handbook of International Relations (OUP 2010) 481, 488-91.

11 J Levy, 'Domestic Politics and War' (1988) 18 J Interdisciplinary History 653, 688. 
a constraint on the EU mission itself. According to the idea of liberal peace, the mission itself is a 'perfectible institution' that must be construed with regard to the liberal ideals, among which the RoL has a prominent place. Underlying the latter argument is the belief that all institutions (domestic or international) can harm individuals. Just by being an 'international' creation, an institution is not dignified or immunized, but (depending on the robustness of the mission's mandate) must itself be tested against the values or principles that it seeks to export or defend. In sum, we propose that the RoL in EU civilian missions does not merely serve as a policy-instrument or good that can be exported, but that the RoL serves as a legal constraint on the mission itself.

This article examines both functions of the RoL in the context of the EU Rule of Law Mission to Kosovo (EULEX). Initially employed in 2008, EULEX is the largest EU civilian mission to date. ${ }^{12}$ It succeeded the UN Mission in Kosovo (UNMIK), which had been created by the Security Council under Chapter VII. ${ }^{13}$ The civilian mission of EULEX is used as a tool to bridge the security gap threatening the stability of Kosovo and the whole region as a result of the Kosovo War. ${ }^{14}$ To fulfil this complex task, EULEX's mandate contains extensive powers to reform Kosovo's public security institutions. At the same time, EULEX is the only EU civilian mission at present endowed with its own executive tasks, thus replacing, or at least complementing, the State authorities in certain areas. Given its unique structure, the hybridity of the RoL as both a constraint and as a policy-tool can be studied.

The question addressed in this article is whether the EU hybrid approach to the RoL offers a normatively desirable mechanism to bridge the security gaps that often arise from post-conflict scenarios. The article is structured as follows: the first part describes the conceptual framework, defining the two main concepts used in the article, 'authority' and the 'RoL', and discusses them in the context of EU civilian missions. The second part addresses the problem of RoL as a constraint on EULEX. The third part deals with the RoL as an instrument of EULEX to advance public security. The article concludes that the hybrid approach to the RoL gives rise to high expectations concerning the performance of EU civilian missions as external 'civilizers'. However, since both functions of the RoL are connected, an inadequately developed and implemented constraint-

H Dijkstra, 'The Planning and Implementation of the Rule of Law Mission of the European Union in Kosovo' (2011) 5 J Intervention and Statebuilding 193.

13 E de Wet, 'The Governance of Kosovo: Security Council Resolution 1244 and the Establishment and Functioning of EULEX' (2009) 103 AJIL 83.

14 A Biava, 'The Emergence of a Strategic Culture within the Common Security and Defence Policy' (2011) 16 European Foreign Affairs Review 41, 46. The non-executive nature of an EU civilian mission is usually mentioned explicitly in the mandate. See, e.g., Council Joint Action 2007/369/CFSP of 30 May 2007 on the Establishment of the European Union Police Mission in Afghanistan (EUPOL AFGANISTAN) [2007] OJ L 139/33, art 4(2); Council Joint Action 2007/405/CFSP of 12 June 2007 on the European Union Police Mission undertaken in the Framework of Reform of the Security Sector (SSR) and its Interface with the System of Justice in the Democratic Republic of the Congo (EUPOL RD Congo) [2007] OJ L 151/46, art 2(2). 
function of the RoL for EU civilian missions has negative repercussions on a mission's ability to rely on the RoL as a policy-tool. Ultimately, insufficiencies of the constraint-function of the RoL may endanger the success of the mission.

\section{Authority of EU Civilian Missions and the Rule of Law}

Civilian missions are a central instrument of the EU's Common Security and Defence Policy and manifest the EU's ambition to emerge as a 'civilizer' on the global level. ${ }^{15}$ The following part clarifies two concepts central to the question raised in this article, 'authority' and the 'RoL'.

\section{A. Types of Authority Exercised by EU Civilian Missions}

EU civilian missions exercise specific types of 'authority'. The concept of 'authority' is of an explanatory value insofar as it captures the circumstances triggering constitutional concerns, among others, the principle of the RoL. For the purpose of this article, we adopt a normative conception of 'authority': authority in a normative sense means 'legitimate authority' as opposed to 'factual' or 'brute' power. ${ }^{16}$ Drawing on a definition by Bogdandy et al, 'authority' means the legitimate capacity of one person to unilaterally alter or impact the conduct or legal position of others. ${ }^{17} \mathrm{EU}$ civilian missions may exercise three different types of authority: they usually exercise 'political authority' when charged with advisory or even (binding) correctional functions in relation to governments and governmental acts. They may exercise 'public authority' when taking (unilateral) binding decisions vis-à-vis private individuals and entities on foreign territory, ${ }^{18}$ and 'institutional authority' by means of organizational acts affecting

15 See Council of the European Union, Abstract of the 2009 Annual Report on the Identification and Implementation of Lessons and Best Practices in Civilian CSDP Missions (11 December 2009) 17487/09.

16 See T Christiano, 'Authority' <http://plato.stanford.edu/entries/authority/> accessed 18 May 2015; B Peters and J Karlsson Schaffer, 'The Turn to Authority Beyond States' (2013) 4 Transnational Legal Theory 315-35.

17 A von Bogdandy, P Dann and M Goldmann, 'Developing the Publicness of Public International Law: Towards a Legal Framework for Global Governance Activities' in A von Bogdandy and others (eds), The Exercise of Public Authority by International Institutions (Springer 2010) 3, 11.

18 A von Bogdandy, P Dann and M Goldmann were among the first to propose that there is in fact such a thing as 'international public authority'. See von Bogdandy, Dann and Goldmann, ibid 3. In contrast to von Bogdandy et al, our definition of 'public authority' is narrower. We reserve the concept for vertical relationships, involving at least one non-state actor. In our view 'public authority' is not exercised in horizontal state-to-state relations (even if, in exceptional circumstances, a state or supranational organization may be authorized to take binding decisions upon another state). 
third parties, eg when acting as a public employer or public contractor on the market. ${ }^{19}$

\section{B. External Exercise of Public Authority as a Rule of Law Problem}

How does the exercise of public authority by EU civilian missions implicate the RoL? From a constitutionalist perspective, it is an enduring inheritance of liberalism that the exercise of public (ie coercive, unilateral) authority vis-à-vis individuals must be restricted by constitutional principles, including the RoL. ${ }^{20}$ The necessity to check and restrain public power does not end when it is exercised by, or shared with, international or regional actors. ${ }^{21}$ Once the territorial State opens up its 'sovereignty shield' and allows international or regional actors to exercise public authority on its behalf, or where it is required to do so by international law, the RoL as a constitutional principle is implied.

On the level of positive law, the principle of the RoL has been firmly established for EU internal relations. In 1986, the RoL was recognized as a constitutional principle of the EU in the landmark decision Les Verts. ${ }^{22}$ The Treaty on European Union (TEU) - as a 'constitutional document' of the EU-makes explicit reference to the RoL at various points. ${ }^{23}$ The situation is less clear, however, with regard to EU external relations, ie acts of EU organs in nonMember States. Article 21(1) TEU holds that the EU shall be 'guided by' and seek to 'advance' the RoL in its external actions. ${ }^{24}$ While the text of the TEU appears to establish rather mild constitutional obligations for EU civilian missions, it cannot be doubted that the EU must also be bound by RoL-principles when exercising public authority 'abroad'. It cannot make a difference where EU organs exercise public authority for the RoL to be implied. ${ }^{25}$ Any deviation

19

Note that this is an ideal-type distinction only. In practice, it may prove difficult to distinguish among the three types of authority. See Human Rights Review Panel (HRRP), Kristian Kahrs v EULEX (2013) 2012-16, para 30 (on the distinction between political and public power of EULEX). On the HRRP see sub-Section III.C M Loughlin, The Idea of Public Law (OUP 2003) 42-45.

This rationale informs the reasoning of the Bosphorus case. See Bosphorus v IRL App no 45036/98 (ECtHR, 30 June 2005), para 153.

Case 294/83 Les Verts v Parliament [1986] ECR 1339, para 23.

TEU [2012] OJ C326/13, Preamble (paras 2 and 4), art 2, arts 21(1) and (2)(b). See also the indirect references in TEU art 7 (serious breach of the values of art 2) and art 49 TEU (accession to EU).

24 TEU [2012] OJ C326/13 art 21(1) reads in full: “"The Union's action on the international scene shall be guided by the principles which have inspired its own creation, development and enlargement, and which it seeks to advance in the wider world: democracy, the rule of law, the universality and indivisibility of human rights and fundamental freedoms, respect for human dignity, the principles of equality and solidarity, and respect for the principles of the United Nations Charter and international law.'”

ILA, 'Draft Articles on the Responsibility of International Organisations' in International Law Association Report of the Sixty-Third Session (Geneva 2011) (International Law Association, Geneva 2011), art 3-4. 
from the general rule - that the RoL applies to any exercise of public authority by the EU-would have to be justified. A mere lack of resources or the (unqualified) reference to a tense public security situation, eg cannot-in our view-justify a deviation of EU external action from RoL-principles. This, in turn, implies that EULEX Kosovo, in so far as it exercises public authority, must adhere to the RoL already by virtue of EU constitutional law.

When does EULEX exercise public authority? In 2008, EULEX took over UNMIK's tasks in the field of police and justice. ${ }^{26}$ Whereas United Nations Security Council Resolution (UNSC Res) 1244 had established 'an international civil and security presence in Kosovo with full civil and political authority and sole responsibility for the governance of Kosovo', ${ }^{27}$ EULEX only retains 'certain executive responsibilities'. ${ }^{28}$ The exercise of executive power by EULEX is a clear case of 'public authority', as defined above, since the mission has the legal capacity to take binding, unilateral decisions on individuals. EULEX is entrusted with the exercise of public authority in four distinct contexts: first, EULEX has executive powers with regard to public security, relating primarily to the police, the office of the public prosecutor and customs. ${ }^{29}$ Second, EULEX has adjudicative powers in relation to specific crimes (war crimes, terrorism, organized crime, corruption etc.). ${ }^{30}$ Third, EULEX may reverse or annul operational decisions taken by the Kosovo authorities (corrective powers). ${ }^{31}$ Fourth, there is a broad provision in EULEX's mandate, holding that EULEX shall 'assume other responsibilities, independently (...) to ensure the maintenance and promotion of the RoL, public order and security, in consultation with the relevant Council agencies' (subsidiary power). ${ }^{32}$

26 Ruhan Ruhani v UNMIK (13 April 2011) Case no 85/09, para 12.

27 Accordance with International Law of the Unilateral Declaration of Independence in Respect of Kosovo (Advisory Opinion) [2010] ICJ Rep 403 para 97.

28 Council Joint Action 2008/124 of 4 February 2008 on the European Union Rule of Law Mission in Kosovo, EULEX Kosovo [2008] OJ L42/92, art 2. On the limited scope of EULEX's executive mandate see also the decision of the HRRP, $H \& G$ against EULEX (2013) 2012-19 and 2012-20, para 41.

29 EULEX operational power is based on Council Joint Action 2008/124 (n 23) arts 3(h), 6(3)(b) and (d), 6(4). See also Law on Jurisdiction and Competencies of EULEX Judges and Prosecutors in Kosovo (2008, Law on Jurisdiction) law no 03/L-053, arts 7-13, 17; the Law on Police (2011) law no 04/L-076; Customs and Excise Code of Kosovo (2008) law no 03/L-109, art 310 as amended by Law on Amending and Supplementing the Laws related to the Mandate of the European Union Rule of Law Mission in the Republic of Kosovo (2014) law no 04/L-273.

30 Council Joint Action 2008/124 (n 28) art 3(d). See also Law on Jurisdiction (n 29) arts 2-6.

31 Council Joint Action 2008/124 ibid art 3(b). See, eg HRRP, Bahadur ao v EULEX (2011) 2011-02, para 46 (inadmissible).

32 Council Joint Action 2008/124 ibid art 3(h). 


\section{Conceptions of the Rule of Law}

EU constitutional law does not provide any guidance as to what conception of the RoL EU civilian missions are obliged to follow. In the literature, three RoLconceptions are predominantly discussed: a formal, a substantive and a functional understanding of the RoL. We argue that-in relation to external EU action - a functional RoL-conception should apply.

The formal understanding of the RoL originates in England in the 18th century and focuses on (technical) restrictions to the exercise of governmental power, such as 'rule by law', 'supremacy of the law', 'equality before the law', 'formal legality', 'open government' and others. ${ }^{33}$ Some have argued that Article 2 TEU contains a formal understanding as it explicitly distinguishes the RoL from other constitutional principles, such as democracy and human rights. ${ }^{34}$ This argument, however, seems too formalistic in our view.

The substantive interpretation of the RoL is often associated with the German idea of the 'Rechtsstaat' and incorporates the idea of 'good' law into the definition by demanding conformity of a legal system with ideals such as democracy, human rights or-even more abstractly-justice and reason. ${ }^{35}$ There are good reasons to believe that the EU follows a substantive conception of the RoL. Pech has argued that the EU 'constitution', viewed as a whole, suggests that the Union's foundational principles are interdependent and must be construed in light of each other. ${ }^{36}$ Similarly, the recently published Commission Framework, which seeks to resolve future threats to the RoL in EU Member States, explicitly states that the RoLprinciples developed by the Court of Justice of the European Union (CJEU), the European Court of Human Rights (ECtHR) and the Venice Commission 'are not purely formal and procedural requirements', but that 'they are the vehicle for ensuring compliance with and respect for democracy and human rights'. ${ }^{37}$

33 See S Chesterman, 'Rule of Law' (MPEPIL 2007) <http://opil.ouplaw.com/view/10. 1093/law:epil/9780199231690/law-9780199231690-e1676?rskey=DpepX5\&result=1\&prd= EPIL> accessed 18 May 2015, para 2.

34 See, with further references, A von Bogdandy and M Ioannidis, 'Systemic Deficiency in the Rule of Law: What It Is, What Has Been Done, What Can Be Done' (2014) 51 Common Market L Rev 59, 62-63.

35 For an instructive overview of different rule of law conceptions see, eg P Craig, 'Formal and Substantive Conceptions of the Rule of Law: An Analytical Framework' (1997) Public Law 467 or T Brian, On the Rule of Law: History, Politics, Theory (CUP 2004) 91-114.

36 L Pech, 'A Union Founded on the Rule of Law: Meaning and Reality of the Rule of Law as a Constitutional Principle of EU Law' (2010) 6 EuConst 359, 368. See also, more recent, L Pech, 'Promoting the Rule of Law Abroad: On the EU's Limited Contribution to the Shaping of an International Understanding of the Rule of Law' in D Kochenov and F Amtenbrink (eds), European Union's Shaping of the International Legal Order (CUP 2014) 111f, 118.

37 Commission Communication, A new Framework to Strengthen the Rule of Law (11 March 2014) COM 2014 4. Pech claims that the EU has formally recognized the Council of Europe's pre-eminence in shaping an original understanding of the rule of law within Europe. The references of the Commission Communication to the case 
According to the document, the RoL is a constitutional principle with both formal and substantive components (as substantiated in the case law of the CJEU and the ECtHR). Besides 'formal' criteria (legality, legal certainty, prohibition of arbitrariness, independent and impartial courts as well as equality before the law), the framework adds 'effective judicial review including respect for fundamental rights' to the definition of the RoL. ${ }^{38}$ In the 'EU Concept for CSDP Justice Missions', the EU decided to follow the substantive RoL-definition of the UN Secretary General. ${ }^{39}$ In practice, the EU has thus accepted a substantive RoL-conception for its external actions.

Finally, there is a functional conception of the RoL. On this account, no fixed (substantive or formal) content can be attached to the RoL. The RoL is considered to be of no intrinsic value as such, but serves other constitutional principles or goals. According to Chesterman, a functional approach looks at the function that the RoL is intended to serve in a given society. ${ }^{40}$ Thus, according to a functional understanding, the RoL caters to the realization of other ideals, such as the prevention of arbitrary government, ensuring human rights-conformity of executive action, fostering stable economic development or the non-violent solution of political disputes. ${ }^{41}$

We endorse a functional conception of the RoL for EU civilian missions. The content of the RoL with regard to external EU actions is dynamic, not fixed. It is determined by taking into account the type of authority a mission exercises. What the RoL requires depends on the type of authority (public, political, or institutional) the EU exercises in the individual case. For example, if a EU civilian mission exercises 'public authority' (where the RoL has the function to constrain such acts), the RoL serves ideals such as preventing arbitrary rule

law of the ECtHR and the documents of the Venice Commission make sense in this light. Pech, 'Promoting the Rule of Law Abroad' (n 36) $120 \mathrm{f}$.

38 ibid 4.

39 Council document 18173/10 of 20 December 2010 laying down the EU concept for CSDP justice missions (EU concept for CSDP justice missions) [2002], para 3.1. Reference is made, ie to the UN definition of the rule of law in the UNSC 'Report of the Secretary-General: The rule of law and transitional justice in conflict and postconflict societies' (2004) UN Doc S/2004/616 [6]: '[Rule of law] refers to a principle of governance in which all persons, institutions and entities, public and private, including the State itself, are accountable to laws that are publicly promulgated, equally enforced and independently adjudicated, and which are consistent with international human rights norms and standards. It requires, as well, measures to ensure adherence to the principles of supremacy of law, equality before the law, accountability to the law, fairness in the application of the law, separation of powers, participation in decision-making, legal certainty, avoidance of arbitrariness and procedural and legal transparency.'

40 S Chesterman, 'An International Rule of Law?' (2008) 56 Am J Comp L 331, 341.

41 ibid 341. Clarifying the distinction between a functional and a substantive approach, he states that resorting to the rule of law as a means to realize certain substantive goals does not mean that one applies a substantive rule of law conception. ibid 344 . Wennerström also discusses a functional approach to the rule of law. E Wennerström, The Rule of Law and the European Union (Iustus Förlag Uppsala 2007) 82f. 
and ensuring human rights-conformity of executive action. Given this function, the RoL essentially requires legal and institutional safeguards (eg access to judicial review) benefiting individual, non-state addressees of public authority acts. In contrast, where EULEX exercises 'political authority' (where the RoL has the function of a policy-tool), the RoL serves ideals such as public security or stable economic development. In this case, the RoL requires, eg accountability mechanisms or instruments to prevent corruption benefiting the overall political situation in the territory.

\section{Rule of Law as a Constraint to EULEX}

This part deals with the first aspect of the EU hybrid approach: the RoL as a constraint to the exercise of public authority by EULEX. How is the constraining-function of the RoL implemented in the case of EULEX? In order to meaningfully assess EULEX's RoL-performance, one needs to distinguish specific RoL-requirements that are designed to prevent arbitrary rule and ensure the human rights-conformity of executive action by EULEX. To formulate specific RoL-requirements, we draw on a recent approach by Bedner who has proposed a 'research tool', differentiating three categories of RoL-requirements: the first category relates to 'procedural elements' (eg rule by law and formal legality), the second concerns 'substantive elements' (eg protection of individual rights and liberties) and the third pertains to 'controlling mechanisms' (eg independent tribunals and courts). ${ }^{42}$ The constraining function of the RoL for EU civilian missions is a crucial factor in guaranteeing that the EU is locally and internationally perceived as a legitimate actor in the provision of security. ${ }^{43}$ As outlined in the introduction, the notion of the RoL as a constraint follows from the application of the idea of liberal peace to the mission itself.

\section{A. Procedural Requirements}

Taking into account that EULEX exercises 'public authority', two procedural requirements of the RoL are particularly important: the 'rule by law' and 'formal legality'. ${ }^{44}$ As applied to EULEX, 'rule by law' requires a constitutional framework that defines the conduct of the mission's organs. EULEX's legal

42 A Bedner, 'An Elementary Approach to the Rule of Law' (2010) 2 Hague J the Rule of L 48, 56-63, 63-67, 67-70.

43 Human Security Study Group (2007), 'A European Way of Security: The Madrid Report of the Human Security Study Group Comprising a Proposal and Background Report' (Madrid, 8 November 2007) 4 <http://eprints.lse.ac.uk/40207/1/ A_European_Way_of_Security(author).pdf $>$ accessed 18 May 2015.

44 This is, of course, not to be understood as a comprehensive list of the constitutive elements of the procedural dimension of the rule of law. Bedner adds two further elements, namely that 'all state action must be subjected to the law' and 'democracy', the examination of which lies outside the scope of this article, see ibid. 
capacity to exercise public authority is determined by a constitutional framework of international, European and, arguably, Kosovar constitutional law.

EULEX formally operates in the framework of UNSC Res $1244 .{ }^{45}$ From a RoL-perspective, the consequences of EULEX's submission to UNSC Res 1244 are drastic: due to the requirement of neutrality regarding Kosovo's status, the EU is formally not authorized to engage in state-building activities. 'Statusneutrality' implies that EULEX has to adhere to the UNMIK body of law when carrying out its executive mandate. This, however, would exclude the laws of Kosovo established under the new Constitution of Kosovo (Constitution) after its independence. ${ }^{46}$ Consequently, EULEX officials would be barred from applying those Kosovar laws they helped drafting (and which were given democratic legitimacy by the Kosovo legislature) ${ }^{47}$ In practice, EULEX tends to ignore this legal implication. ${ }^{48}$ Regarding EULEX's basis in EU constitutional law, the mission was established under Article 14 TEU (postLisbon Article 28 TEU) and Article 25(3) TEU (post-Lisbon Article 38(3) TEU). ${ }^{49}$ The mission is carried out within the framework of the Common Security and Defence Policy (CSDP), a largely intergovernmental field of EU action, which leads to limited judicial review ${ }^{50}$ and minimal involvement of the European Parliament. ${ }^{51}$ From a RoL-perspective, both result in a reduced accountability of the EU in this policy field. ${ }^{52}$ Lastly, Kosovar constitutional law is relevant since it defines the space in which the (new) Kosovar state has opened up its 'sovereignty shield' and integrated the exercise of public authority by international actors into its domestic legal order. ${ }^{53}$ The Constitution mentions EULEX only once. ${ }^{54}$ However, EULEX may be regarded as an 'other actor mandated under the Comprehensive Proposal for the Kosovo Status Settlement'

45 UNSC 'Report of the Secretary-General on the United Nations Interim Administration Mission in Kosovo of 24 November 2008' (2008) UN Doc S/2008/ 692, para 50.

46 W Koeth, 'State Building without a State: The EU's Dilemma in Defining Its Relations with Kosovo' (2010) 15 Eur Foreign Affairs Rev 227, 238 (pointing to the fact that UNMIK, after Kosovo's declaration of independence in 2008, ceased to

ibid.

49 Council Joint Action 2008/124 (n 28).

50 See TEU [2012] OJ C326/13 art 24(1) in conjunction with the Treaty on the Functioning of the European Union (TFEU) OJ C326/55, art 275.

51 TEU [2012] OJ C326/13 art 36.

52 B van Vooren and RA Wessel, EU External Relations Law (CUP 2014) 375-79.

53 The relevance of Kosovar constitutional law for EULEX may be questionable if one considers UNSC Res 1244 as the sole (international law) basis of the European mission. Given the constitutional reality of the Kosovar state, however, this position does not seem tenable to us anymore. See R Muharremi, 'The European Union Rule of Law Mission in Kosovo (EULEX) from the Perspective of Kosovo Constitutional Law' (2010) 70 ZaöRV 357.

54 Constitution of 7 April 2008 art 151(2) <http://www.kushtetutakosoves.info/ ?cid $=2,302>$ accessed 18 May 2015 . 
(Ahtisaari Plan) $)^{55}$ with which 'all authorities in the Republic of Kosovo shall cooperate fully' and to whose 'decisions or acts' they 'shall (...) give effect'. The Ahtisaari Plan refers to the 'European Security and Defence Policy (ESDP) Mission' in Annex X. ${ }^{57}$ The Constitution, thus, endows EULEX with constitutional status, taking precedence over all legal provisions, which, arguably, includes the Constitution itself. ${ }^{58}$

Another procedural element of importance when restraining public authority is the 'principle of legality'. ${ }^{59}$ The principle of formal legality is often considered to entail (at least) three sub-requirements: that acts of a 'public authority' must have a legal basis, that the legal basis be accessible and that the wording must be sufficiently clear. ${ }^{60}$ The executive tasks of EULEX in the field of policing, justice and customs are based on its mandate. ${ }^{61}$ In addition, EULEX officials are required to respect the applicable local laws. This obligation flows from Article 41(1) Vienna Convention on Diplomatic Relations of 1961, which applies to EULEX personnel as an international legal obligation. ${ }^{62}$ This provision, however, is unenforceable as a result of the privileges and immunities granted to EULEX. ${ }^{63}$

There has also been criticism with regard to the insufficiently clear framing of EULEX's public authority-powers. One problem is the ambiguity of the different

55 Letter dated 26 March 2007 from the Secretary-General addressed to the President of the Security Council' (2007) UN Doc S/2007/168/Add 1 (Ahtisaari Plan).

56 Constitution (n 54) art 146(1) and (2).

57 Ahtisaari Plan (n 55).

58 According to Constitution art 143(2) and art 143(3), the Ahtisaari Plan takes precedence over all laws in Kosovo, which includes the Constitution. In turn, the Ahtisaari Plan explicitly provides for the presence of the international community in Kosovo.

59 Bedner (n 42) 60-62.

60 For Raz, laws further need to be prospective, adequately publicized and not be changed too often. J Raz, 'The Rule of Law and its Virtue' in J Raz (ed), The Authority of Law (2nd edn, OUP 2009) 214. For Fuller, legality additionally requires that rules are constant through time, intelligible, only demand the possible, consistent with one another, known to the citizen and observed by the legal actors charged with their administration according to their annunciation. L Fuller, The Morality of Law (New Haven, revised edn, YUP 1969) 46-91.

61 Council Joint Action 2008/124 (n 28) art 3.

62 According to M Spernbauer, UNMIK Reg no 2000/47 'on the status, privileges and immunities of KFOR and UNMIK and their personnel in Kosovo' also applies to EULEX based on UNMIK executive decision UNMIK Reg no 2008/36. M Spernbauer, EU Peacebuilding in Kosovo and Afghanistan (Martinus Nijhoff Publishers 2014) 354 n 1538. Section 3.5 of UNMIK Reg no 2000/47 states that UNMIK personnel shall respect the laws applicable in the territory of Kosovo in the fulfilment of their mandate... and refrain from any action or activity incompatible therewith. The same, consequently, applies to EULEX personnel.

63 Law on the Status, Immunities and Privileges of Diplomatic and Consular Missions and Personnel in Republic of Kosova and of the International Military Presence and its Personnel (2008) law no 03/L-033 or, based on international law, UNMIK Reg no 2000/47 'on the status, privileges and immunities of KFOR and UNMIK and their personnel in Kosovo', which equally applies to EULEX personnel. 
language versions of the reverse and annulment-power as to whether prior consultation of the relevant international civilian authorities is mandatory or discretionary for EULEX. ${ }^{64}$ Another problem is the broad wording of EULEX's subsidiary power. ${ }^{65}$ Additionally, one of the central planning documents of the mission, the Operation Plan (OPLAN) ${ }^{66}$ is a restricted document, giving rise to concerns with regard to the accessibility of the legal basis and the transparency of EULEX. The greatest concern in the context of formal legality, however, is the amalgamation of international, European and Kosovar law. All of these legal regimes interact when EULEX's 'public authority' is at stake. Given this complex interplay of legal regimes in Kosovo, it is not surprising that some qualify 'its legal framework, which is an unclear and inconsistent mix of former Yugoslav, UNMIK and more recent legislation' as a central problem. ${ }^{67}$

\section{B. Substantive Requirements}

A substantive RoL-requirement is the conformity of all laws and legal acts with human rights. ${ }^{68}$ The exercise of public authority demands compliance with human rights and there is no reason to treat EU internal or external action differently in this regard. Its mandate requires EULEX to "ensure that all its activities respect international standards concerning human rights and gender mainstreaming' without, however, specifying these. ${ }^{69}$ In its jurisprudence, the HRRP regularly refers to the obligation of EULEX to comply with international standards of human rights. ${ }^{70}$ These 'international standards' are primarily the European Convention on Human Rights (ECHR) and UNSC Res 1325 (2000) on Women, Peace and Security. ${ }^{71}$ A look at the practice of the HRRP confirms that the Panel predominantly relies on the ECHR. ${ }^{72}$ To this, the International Covenant on Civil and Political Rights (ICCPR) and the Charter of Fundamental Rights of the European Union can be added. ${ }^{73}$

64 M Spernbauer, 'EULEX Kosovo: The Difficult Deployment and Challenging Implementation of the Most Comprehensive Civilian EU Operation to Date' (2010)

11 German LJ 769, 785.

65 Council Joint Action 2008/124 (n 28) art 3(h).

66 According to ibid art 4(4), the EU Planning Team draws up the OPLAN while the Council approves the document. The OPLAN contains central information regarding EULEX's structure and operationalization. See, eg ibid arts 6(3) and 14(5).

67 E Schleicher, Positive Peace in Kosovo (Peter Lang 2012) 130.

68 Bedner (n 37) 63-67.

69 Council Joint Action 2008/124 (n 23) art 3(i).

70 HRRP, $H$ \& $G$ against EULEX (2013) 2012-19 and 2012-20, para 42. On the HRRP see sub-Section III.C.

71 Spernbauer, 'EULEX Kosovo' (n 64) 786.

72 HRRP Annual Report 2014, 9, <http://www.hrrp.eu/annual-report.php> accessed 18 May 2015.

73 EU concept for CSDP justice missions (n 39) 10 (which additionally mentions international standards contained in international human rights law, international humanitarian law, international criminal law and international refugee law). 
Even though the Kosovar Constitution as such does not create enforceable obligations for EULEX, one can argue that the Kosovar government has a subsidiary duty to ensure that the practice of EULEX remains within the boundaries of the Constitution. The Constitution in Chapter II contains a comprehensive catalogue of fundamental rights and freedoms. Additionally, eight international human rights instruments are directly applicable in Kosovo, according to Article 22. Article 3 of the Constitution guarantees that the exercise of public authority in Kosovo 'shall be based upon the principles of equality of all individuals before the law and with full respect for internationally recognized fundamental rights and freedoms.' EULEX exercises such public authority in Kosovo. If the Kosovar parliament ratifies an international agreement that delegates State powers to EULEX according to Article 20(1) of the Constitution, ${ }^{74}$ one may argue that the responsibility to ensure that EULEX respects fundamental rights and freedoms, as enshrined in the Constitution, rests with the Kosovar government itself. A similar idea is captured in international law when the ECtHR holds states responsible under Article 1 ECHR for all acts and omissions of their organs, even if acting in compliance with international legal obligations. ${ }^{75}$ A Member State cannot free itself from its (human rights) obligations by opening up its sovereignty shield and allowing international actors to perform acts of public authority on its territory. ${ }^{76}$ In other words, the Kosovar government is required to ensure that all legal acts of EULEX remain within the limits of the Kosovar Constitution.

\section{Controlling Requirements}

The last RoL-requirement essential to constraining the exercise of public authority concerns controlling mechanisms that allow for an 'authoritative determination' of whether laws have been broken. ${ }^{77} \mathrm{~A}$ functional RoL-approach demands a sufficient form of judicial review of public authority acts by EULEX. Unfortunately, the mission exhibits deficiencies in this regard.

In 2006, the UNMIK Human Rights Advisory Panel (HRAP) was established. ${ }^{78}$ In 2009, the EU installed a similar body, the HRRP, to review acts

74 See Law on Ratification of the International Agreement between the Republic of Kosovo and the European Union on the European Union Rule of Law Mission in Kosovo (2014) law no 04/L-274.

75 Bosphorus v IRL (n 21) 153. Kosovo is not a formal member of the Council of Europe, but its Constitution declares the ECHR (and, arguably, the case-law of the ECtHR) to be directly applicable in Kosovo, see art 22(2) of the Constitution.

76 A Peters and T Altwicker, Europäische Menschenrechtskonvention (CH Beck 2012) 17.

77 That the rule of law demands something like courts is claimed by $\mathrm{J}$ Waldron, 'The Concept and the Rule of Law' (2008) 43 Georgia L Rev 1, 20-21.

78 UNMIK Reg no 2006/12 of 23 March 2006 established the Human Rights Advisory Panel, which was the first international body to receive individual complaints against an UN Administration. 
of EULEX. ${ }^{79}$ The HRRP has jurisdiction to review alleged human rights violations by EULEX Kosovo in the conduct of its executive mandate. ${ }^{80}$ The panel is not a court in the sense of Article 6 ECHR as it does not have the power to normatively alter the complainant's legal position. ${ }^{81}$ It may only establish a human rights violation and make recommendations to the EULEX's Head of Mission for remedial action (apart from compensation). ${ }^{82}$ Given the limited judicial review through the HRRP established by the EU, Nolte and Aust argued that 'the EU is not prepared to subject itself to the same standards of binding judicial review which it requires, for example, of candidates as a condition for joining the Union'. ${ }^{83}$ Similarly, the Venice Commission concluded that EULEX's supportive and corrective acts should be put under a more stringent review in a generally peaceful situation, as opposed to the initial post-conflict emergency context. ${ }^{84}$

\section{Rule of Law as a Policy-Tool to Establish Public Security}

The last part discusses the second aspect of the EU hybrid approach, according to which the RoL serves as a policy-tool to establish and maintain public security $^{85}$ in post-conflict scenarios. ${ }^{86}$ The choice of the RoL as a tool to establish public security in Kosovo directly results from Article $21 \mathrm{TEU}$, which counts the RoL among the principles that shall guide the Union's action on the international scene and that it shall seek to advance in the wider world. It also reflects the conviction that the RoL is imperative for the establishment of sustainable security. The employment of the RoL as a policy-tool to advance public security in Kosovo is further evidenced by the mission statement establishing EULEX to assist Kosovo in the path towards sustainable stability. ${ }^{87}$ The use of the RoL as a

79 The legal basis establishing the HRRP is a restricted document. See Venice Commission Opinion no 545/2009 'On the Existing Mechanisms to Review the Compatibility with Human Rights Standards of Acts by UNMIK and EULEX Kosovo' (2010) CDL-AD 051, para 53 no 17 (Venice Commission Accountability Opinion).

80 HRRP Rules of Procedure (HRRP RoP) r 25(1) <http://www.hrrp.eu/reference-documents.php $>$ accessed 10 June 2014.

81 On the criteria see Peters and Altwicker (n 76) 145.

82 HRRP RoP (n 80) r 34.

$83 \mathrm{G}$ Nolte and H Ph Aust, 'European Execptionalism?' (2013) 2 Global Constitutionalism 407, 421.

84 Venice Commission Accountability Opinion (n 79) para 58.

85 TEU [2012] OJ C326/13 art 42(1) authorizes the EU to employ civilian missions outside the Union for the purposes of peace-keeping, conflict prevention and the strengthening of international security. TEU art 43(1) further explains that the tasks referred to in art 42(1) include, among others, post-conflict stabilization.

86 This applies to rule of law substitution missions. Council, Comprehensive EU Concept for Missions in the Field of Rule of Law in Crisis Management, Council doc 9792/03, 4f. See also EU concept for CSDP justice missions (n 39) 20.

87 Council Joint Action 2008/124 (n 28) preamble, para 7. 
policy-instrument to establish public security is implied by the exercise of 'political authority'. EULEX's mandate authorizes the exercise of 'political authority' at various points. Generally, EULEX shall monitor, mentor and advise the competent Kosovo institutions on all areas related to the wider RoL. ${ }^{88}$ Furthermore, the mission disposes of a police and a customs component to support and advise local institutions. ${ }^{89}$ Additionally, EULEX is instructed to support the judicial sector. ${ }^{90}$

What are the identified risks to public security that need to be addressed by EULEX's political authority? The mandate generally highlights measures against corruption and organized crime, ${ }^{91}$ two serious security concerns in the area. ${ }^{92}$ Another factor is the implications of Kosovo's multi-ethnicity, a crucial driver of the past conflict and a source of serious political tension in present-day Kosovo. Accordingly, EULEX is to develop and strengthen a multi-ethnic justice system, police and customs service. ${ }^{93}$

The approach of using the RoL as a tool to advance public security rests on two assumptions, namely, that the RoL and public security are connected and that public security can be 'created' by improving RoL-standards.

It is commonly assumed that the RoL and public security are connected. ${ }^{94}$ Precisely how these two concepts relate to each other, however, is not sufficiently clear. First, public security can be viewed as a necessary precondition for the RoL, ie without public security, the RoL can neither be established nor maintained. From this perspective, 'public security' is understood as a factual conditio sine qua non for a functioning RoL. This is why the World Justice Project-when measuring the RoL-performance of states-measures factors such as 'crime control'. 95 This idea also informed early EU civilian missions with their focus on the 'strengthening of local police forces', which was considered crucial for reinstalling the RoL. ${ }^{96}$ Second, the reverse also holds true: a functioning RoL can be qualified as a necessary condition to create and maintain public security, ie without RoL-conformity there can be no (or at least

88 ibid art 3(a).

89 ibid art 6(3)(b) and (d).

90 ibid art 3(d).

91 Art 3(e) instructs EULEX to strengthen cooperation and coordination throughout the whole judicial process, particularly in the area of organized crime; art 3(f) requires the mission to contribute to the fight against corruption, fraud and financial crime and art $3(\mathrm{~g})$ mandates EULEX to contribute to the implementation of the Kosovo AntiCorruption Strategy and Anti-Corruption Action Plan.

92 Committee on Legal Affairs and Human Rights, 'Inhuman Treatment of People and Illicit Trafficking in Human Organs in Kosovo' (7 January 2011) Dick Marty Report, doc 12462 , para 11.

93 Council Joint Action 2008/124 (n 28) art 2.

94 UNGA 'Report of the Secretary-General: An Agenda for Peace' (1992) UN Doc A/ 47/277 [59].

95 That 'crime is effectively controlled' is a subitem of Factor 5 'Order and Security' of the World Justice Project Rule of Law Index 2014, 8.

96 Similarly, Spernbauer, 'EULEX Kosovo' (n 54) 772. 
significantly less) public security. ${ }^{97} \mathrm{UN}$ and EU policy documents require that public security be attained within a rule of law framework. ${ }^{98}$ This relationship between the RoL and security is also why the European Council identified the strengthening of the rule of law as a necessary concurrent to the strengthening of police capabilities in EU civilian crisis management. ${ }^{99}$ The idea is that 'a democratically run, accountable and efficient security system helps reduce the risk of conflict, thus creating an enabling environment for development'. ${ }^{100}$ This means that there can be no sustainable security without compliance with RoLstandards. Consequently, it seems appropriate to view public security and the RoL as mutually constitutive concepts. On the one hand, the level of public security on the ground impacts the degree to which one may speak of a system based on the RoL, ie public security is functionally related to the RoL (functional relation). On the other hand, public security without the RoL is illegitimate (normative relation).

The second assumption poses more problems. Can public security actually be exported by establishing the RoL? Some argue that the international agenda on public security and the RoL should be separated. ${ }^{101} \mathrm{~A}$ first argument relates to a conceived difference in objectives: while the security agenda relates to the strengthening of State law enforcement capacities, the RoL-agenda aims at restricting it. ${ }^{102}$ Another argument in favour of separation is primarily about efficiency: technical assistance to reform the security sector can be provided by States and international organizations relatively easily and with measurable success, while transformational aspirations-related to normative commitments, such as the RoL-are considered harder to transplant, generating less tangible results. ${ }^{103}$ The RoL is not an easily transplanted commodity. Apart from the respective institutions, a functioning RoL presupposes, so it is argued, a set of normative commitments and beliefs about the State and society. ${ }^{104}$ Some authors therefore caution that there are 'no short-cuts to developing the RoL; in

${ }^{97}$ In this context 'public security' is understood in a normative sense: a 'legitimate' public security framework is one that builds upon the RoL.

98 See, eg UNGA 'Report of the Secretary-General 62/659' (2008) UN Doc A/62/659 [1] and EU Concept for ESDP Support to Security Sector Reform (SSR), 13 October 2005, 12566/4/05 REV 4, paras 17 and 20.

99 Appendix 3 to the Presidency Conclusions, Santa Maria da Feira European Council 19 and 20 June 2000.

100 OECD DAC, The OECD DAC Handbook on Security System Reform (SSR) 13.

101 UC Schröder and J Kode, 'Rule of Law and Security Sector Reform in International State-Building: Dilemmas of Converging Agendas’ (2012) 4 Hague J Rule of L 31.

102 ibid.

103 ibid 45.

104 ibid 37 (arguing that international rule of law assistance 'risks degrading rule of law to a mere institutional blueprint'). This last point reminds of a famous dictum by the German constitutional lawyer EW Böckenförde, who claimed that ' $[t]$ he liberal, secular State builds on preconditions the existence of which it cannot guarantee by itself'. EW Böckenförde, Staat, Gesellschaft, Freiheit (Suhrkamp 1976) 60 ('Der freiheitliche, säkularisierte Staat lebt von Voraussetzungen, die er selbst nicht garantieren kann' [translation by the authors]). Adapted to the situation at issue here, the argument 
any country, the realization of the RoL is the result of protracted struggle by many people and organizations on many different fronts over a long period of time'. ${ }^{105}$ To many, a simple 'copy and paste-strategy' of the EU internal RoLconception to its external relations, therefore, does not seem appropriate.

There are, however, good reasons in our view to assume that public security, achieved by means of establishing the RoL, is a 'good' that can be exported: on normative grounds the EU must defend the instrumental relationship between public security and the RoL, as outlined above, also for its external actions. The RoL is a necessary corollary of legitimate public security. Public security can neither be enforced, nor can the security sector be reformed without orientation on RoL-standards. Furthermore, it would negatively affect the EU's credibility as an external actor if it would export standards that lag behind its internal ambitions.

\section{Conclusion: Bridging the Security Gap through an EU Rule of Law?}

Is the EU hybrid approach to the RoL - as a constraint and as a policy-tool - a promising model to bridge security gaps in post-conflict scenarios? From a normative perspective, the EU must be applauded for its attempt to bridge the security gap through a hybrid RoL-approach. The deployment of civilian capabilities, such as EULEX, reflects the EU awareness of security gaps stemming from a new type of security threat that cannot be addressed by military means only. ${ }^{106}$ The destabilizing factors that EULEX confronts in Kosovo, such as corruption, organized crime and inter-ethnic tensions, cannot be solved with recourse to military capabilities.

However, it must be observed that deficiencies of one RoL-function will impact the success of the other as they are closely connected. The effectiveness of the EU endeavour to export public security hinges on how the EU handles its own RoL-problems regarding the external exercise of public authority. Additionally, the fact that Kosovo is integrated in the Stabilization and Association Process, and therefore a potential candidate for a future EU enlargement, blurs the line between EU internal and external security, further strengthening the argument for an effective constraining function of the RoL to avoid the creation of a 'legitimacy gap' while closing the 'security gap'. EU civilian missions with a clear executive mandate, such as EULEX, must comply

would be that the necessary preconditions for a functioning rule of law cannot be 'installed' by a European civilian mission.

105 R Peerenboom, 'The Future of Rule of Law: Challenges and Prospects for the Field' (2009) 1 Hague J Rule of L 5, 14.

106 Human Security Study Group (2007), 'A European Way of Security: The Madrid Report of the Human Security Study Group Comprising a Proposal and Background Report' (Madrid, 8 November 2007) $23<$ http://eprints.lse.ac.uk/40207/ 1/A_European_Way_of_Security(author).pdf $>$ accessed 18 May 2015. 
with EU RoL-standards in practice. In this regard, EULEX exhibits huge shortcomings, not all of which can be attributed to the precarious situation resulting from the amalgamation of international, European and Kosovar law. Eventually, the EU's success as an external actor may not stumble over the fact that EULEX did not manage to solve the actual public security problems of Kosovo, but over its own RoL-deficit. ${ }^{107}$

There will be demand for robust and comprehensive EU civilian missions elsewhere in the world. Public security, in ever more places, will depend on RoL-export. It seems crucial that EU civilian missions, when exercising authority abroad, act according to EU constitutional principles, among which the RoL is of central importance. Not only must the RoL be exported, it must be lived by EU civilian missions themselves.

107 See W Koeth, 'State Building without a State: The EU's Dilemma in Defining Its Relations with Kosovo' (2010) 15 Eur Foreign Affairs Rev 227, 246; R Muharremi, 'The European Union Rule of Law Mission in Kosovo (EULEX) from the Perspective of Kosovo Constitutional Law' (2010) 70 ZaöRV 357, 379. 